\title{
Early impact of liraglutide in routine clinical use ( $A B C D$ nationwide liraglutide audit) on cardiovascular risk (UKPDS risk engine)
}

\author{
CHRIS WALTON, ${ }^{1}$ SAIFUL KASSIM, ${ }^{2}$ ROY HARPER, ${ }^{3}$ PAULA MCDONALD, ${ }^{3}$ URSULA BRENNAN, ${ }^{3}$ \\ JANET HARDING ${ }^{3}{ }^{3}$ THEIN HTAY, ${ }^{4}$ RAHUL NAYAR, ${ }^{5}$ ANDREW PERNET, ${ }^{6}$ SUSANNAH ROWLES, ${ }^{7}$ \\ KAREN ADAMSON, ${ }^{8}$ KEN Y THONG,${ }^{9}$ ROBERT EJ RYDER, ${ }^{10}$ ON BEHALF OF ABCD NATIONWIDE \\ LIRAGLUTIDE AUDIT CONTRIBUTORS
}

\begin{abstract}
Aims: Liraglutide has been shown to reduce cardiovascular mortality in a cardiovascular safety study, but it is not known to what extent these results will be replicated in real practice with people with diabetes treated with liraglutide in the UK. We wished to explore the likely cardiovascular benefits by modelling 10-year reduction in cardiovascular events and mortality using data from the $A B C D$ liraglutide audit database.

Methods: The UKPDS risk engine $\mathbf{2} .0$ was applied to data collected in the ABCD liraglutide audit database before and at the earliest return to clinic between 3 and 9 months after commencing liraglutide, using the 747 of 6,959 records where all factors used by the risk engine were completely recorded.

Results: There were significant falls in all factors used in the UKPDS cardiovascular disease (CVD) risk assessment other than HDL cholesterol which was unchanged. The UKPDS risk engine mean \pm SD 10-year coronary heart disease (CHD) risk fell by $2.7 \pm 7.6 \%$ from $18.7 \pm 13.0 \%$ to $16.1 \pm 11.6 \%(p<0.001)$. The 10-year fatal CHD risk fell by $2.3 \pm 6.5 \%$ from $13.7 \pm 11.1 \%$ to $11.4 \pm 9.8 \%(p<0.001)$. The 10 -year stroke risk fell by $0.3 \pm 2.8 \%$ from $7.9 \pm 8.7 \%$ to $7.6 \pm 8.3 \%(p=0.003)$. The 10 -year fatal stroke risk fell by $0.1 \pm 0.7 \%$ from $1.2 \pm 1.4 \%$ to $1.1 \pm 1.3 \%$ $(p=0.001)$.
\end{abstract}

Conclusion: Starting liraglutide reduced 10-year CVD risk.

Hull Royal Infirmary, Hull, UK

Northern HSC, Antrim, UK

The Ulster Hospital, Dundonald, UK

Kingston Hospital, London, UK

City Hospitals, Sunderland, UK

King's College Hospital, London, UK

Pennine Acute Hospitals, Manchester, UK

8 St John's Hospital, Livingston, UK

9 School of Medicine and Pharmacology, Perth, Australia

${ }^{10}$ City Hospital, Birmingham, UK

Address for correspondence: Chris Walton

Hull Royal Infirmary, Brocklehurst Building, 220-236 Anlaby Road, Hull, HU3 2RW

E-mail: chris.walton@hey.nhs.uk

https://doi.org/10.15277/bjd.2020.243
These data suggest that liraglutide used in routine clinical care in 100 patients could prevent three events of CHD or stroke and save two or more lives over the next 10 years.

Br J Diabetes 2020;20:25-27

Key words: liraglutide, cardiovascular risk, $A B C D$ ationwide audit, UKPDS risk engine, numbers needed to treat

\section{Introduction}

Liraglutide has been shown to reduce cardiovascular outcomes in patients at high risk of cardiovascular disease (CVD). ${ }^{1}$ Uncertainty exists regarding the impact of liraglutide on CVD risk in routine clinical care. The United Kingdom Prospective Diabetes Study (UKPDS) CVD risk engine version $2.0^{2}$ uses recognised risk factors to calculate future CVD risk. Our aim was to establish the predicted impact of liraglutide in routine use in the UK on 10-year CVD risk.

\section{Methods}

We used data from the Association of British Clinical Diabetologists (ABCD) nationwide liraglutide audit, ${ }^{3}$ which assesses liraglutide in routine clinical practice. The audit database comprises data on 6,959 patients from 163 centres in the UK between 2009 and 2017. The daily dose of liraglutide prescribed was $1.2 \mathrm{mg}(84 \%)$, $0.6 \mathrm{mg}(9 \%)$ and $1.8 \mathrm{mg}(6 \%)$. For this analysis we included all patients with all the factors used by the risk engine (age, duration of diabetes, ethnicity, systolic blood pressure, $\mathrm{HbA}_{1 c}$, total cholesterol and $\mathrm{HDL}$ cholesterol) measured before and at the earliest return to clinic between 3 and 9 months after commencing liraglutide. As we did not have data on atrial fibrillation, smoking or previous CVD, these were assumed to be absent for the purposes of the analysis.

\section{Results}

Table 1 shows the baseline characteristics of those 747 patients with complete datasets and the early impact of liraglutide treatment on CVD risk factors. The reasons for incomplete datasets include the fact that the data did not exist (unavoidable in an observational clinical audit of this nature or not input by contributors). The liraglutide database holds no demographic or social data.

There were statistically significant falls in all factors used in the UKPDS CVD risk assessment other than HDL cholesterol which was unchanged. The UKPDS risk engine mean \pm SD 10-year coronary 
Table 1 Baseline characteristics of the 747 patients who returned to clinic between 3 and 9 months after starting liraglutide and the change in cardiovascular risk parameters at the return visit as mean+SD or median (interquartile range [IQR]). Weight and BMI measurements in 3535 patients during the same time interval. P-values reflect change from baseline

\begin{tabular}{|c|c|c|c|c|}
\hline Parameter & Baseline & At 3-9 months & Difference & $P$ value \\
\hline $\begin{array}{l}\text { Ethnicity: \%White } \\
\% \text { Afro-Caribbean } \\
\% \text { Asian-Indian }\end{array}$ & $\begin{array}{l}89.2 \\
2.9 \\
7.9\end{array}$ & & & \\
\hline $\mathrm{HbA} 1 \mathrm{c}(\mathrm{mmol} / \mathrm{mol})$ & $77.2 \pm 18.0$ & $67.4 \pm 18.6$ & $-9.8 \pm 17.9$ & $<0.001$ \\
\hline $\mathrm{HbA} 1 \mathrm{c}(\%)$ & $9.2 \pm 1.6$ & $8.3 \pm 1.7$ & $-0.9 \pm 1.6$ & $<0.001$ \\
\hline Systolic Blood Pressure (mmHg) & $136.8 \pm 16.6$ & $133.3 \pm 17.3$ & $-3.5 \pm 17.7$ & $<0.001$ \\
\hline Serum total cholesterol (mmol/L) & $4.22 \pm 1.57$ & $3.97 \pm 1.01$ & $-0.25 \pm 1.45$ & $<0.001$ \\
\hline BMI $\left(\mathrm{kg} / \mathrm{m}^{2}\right)(\mathrm{n}=3535)$ & $38.7 \pm 7.0$ & $37.8 \pm 6.9$ & $-0.98 \pm 2.2$ & $<0.001$ \\
\hline
\end{tabular}

heart disease (CHD) risk fell by $2.7 \pm 7.6 \%$ from $18.7 \pm 13.0 \%$ to $16.1 \pm 11.6 \%(p<0.001)$ and the 10-year fatal CHD risk fell by $2.3 \pm 6.5 \%$ from $13.7 \pm 11.1 \%$ to $11.4 \pm 9.8 \%$ ( $<<0.001)$. The 10 -year stroke risk fell by $0.3 \pm 2.8 \%$ from $7.9 \pm 8.7 \%$ to $7.6 \pm 8.3 \%(p=0.003)$ and the 10 -year fatal stroke risk fell by $0.1 \pm 0.7 \%$ from $1.2 \pm 1.4 \%$ to $1.1 \pm 1.3 \%(p=0.001)$.

Starting liraglutide in our study therefore reduced the 10-year cardiovascular event risk by $3.0 \%(2.7 \%+0.3 \%)$ and the 10 -year cardiovascular death risk by $2.4 \%(2.3 \%+0.1 \%)$. The number needed to treat to prevent one cardiovascular event over 10 years was 33 and to prevent one death over 10 years was 42 .

Weight, which is not a factor used in the UKPDS risk engine, was assessed in the 3,535 patients in the audit with weight and body mass index (BMI) data during the same time interval. Weight fell by $2.8 \pm 6.1 \mathrm{~kg}$ from $110.0 \pm 22.3 \mathrm{~kg}$ to $107.9 \pm 22.1 \mathrm{~kg}(\mathrm{p}<0.001)$ and BMI by $0.98 \pm 2.2 \mathrm{~kg} / \mathrm{m}^{2}$ from $38.7 \pm 7.0 \mathrm{~kg} / \mathrm{m}^{2}$ to $37.8 \pm 6.9 \mathrm{~kg} / \mathrm{m}^{2}$ $(p<0.001)$.

\section{Discussion}

The Leader study has shown that the rate of the first occurrence of death from cardiovascular causes, non-fatal myocardial infarction or non-fatal stroke among patients with type 2 diabetes mellitus was lower with liraglutide than with placebo. Over the median of 3.8 years of follow-up there were significantly fewer cardiovascular deaths in patients treated with liraglutide (4.7\%) compared with placebo (6.0\%). If this difference in cardiovascular deaths is extrapolated to 10 years, then the estimated difference in the number of cardiovascular deaths is $3.4 \%$.

The Leader study entrance criteria required the presence of high cardiovascular risk: $81.3 \%$ had prior CVD and $18.7 \%$ had a high risk but without prior CVD. ${ }^{4}$ In comparison, in this modelling study based on the ABCD liraglutide audit database, although many of the pop- ulation had high cardiovascular risk, the population was selected only because a clinician had decided that someone with diabetes was likely to benefit from liraglutide; we do not know what proportion of patients in the audit had previous CVD but if - as is likely - a greater proportion than in the Leader study did not have established CVD, then a lower level of risk reduction would be expected. Starting liraglutide in our study reduced 10-year cardiovascular event risk by $3.0 \%$ and 10 -year cardiovascular death risk by $2.4 \%$. The number needed to treat to prevent one cardiovascular event over 10 years was 33 and to prevent one death over 10 years was 42 . For statins, a meta-analysis of studies performed before 1999 indicated that the number needed to treat to prevent one cardiovascular death over 5 years was $20 .^{5}$ Unlike statins, however, the benefits of liraglutide are not confined to reducing cardiovascular risk.

The importance of collecting real-world audit data is illustrated by the difference in the populations of people with diabetes treated in the UK compared with the population studied within the Leader study. The mean BMI of people with diabetes in the ABCD liraglutide audit was $38.7 \mathrm{~kg} / \mathrm{m}^{2}$ compared with a mean BMI of $32.5 \mathrm{~kg} / \mathrm{m}^{2}$ in the Leader study. Obesity is an independent risk factor for $\mathrm{CHD}$ events. ${ }^{6,7} \mathrm{BMI}$ is not included on the UKPDS risk engine so, arguably, the cardiovascular benefits found in this study might be an underestimate.

As this study used the earliest assessment after commencement of liraglutide, it is possible that the impact would be greater with longer follow-up. However, it is also possible that, in some patients, the initial reductions in risk factors would not be maintained so the benefits would be less.

Considering changes in single cardiovascular risk factors, for systolic blood pressure there was a significant mean fall of $3.5 \mathrm{mmHg}$ in the 747 people whose data were used in the analysis. This is comparable to a fall in systolic blood pressure of $3.18 \mathrm{mmHg}$ found in a 


\section{Key messages}

- Calculation of cardiovascular risk over 10 years using the UKPDS risk engine applied to the ABCD liraglutide audit database suggests that the cardiovascular benefits seen in the Leader study will also be seen in real-world clinical practice in the UK

- According to the UKPDS risk engine, the number needed to treat with liraglutide over 10 years to prevent one death would be 42

- The number needed to treat with liraglutide over 10 years to prevent one heart attack or stroke would be 33

meta-analysis of 18 randomised controlled trials; 8 however, in the meta-analysis the difference was no longer significant when liraglutide treatment continued beyond one year.

With respect to lipids, there was a $0.25 \mathrm{mmol} / \mathrm{L}$ fall in total cholesterol levels but no significant change in HDL levels. These findings are similar to those reported in a meta-analysis in $2015^{9}$ and two subsequent studies. ${ }^{10,11}$

For $\mathrm{HbA}_{1 \mathrm{c}}$, the fall of $9.8 \mathrm{mmol} / \mathrm{mmol}(0.9 \%)$ is comparable to that seen in those phase 3 studies which included the $1.2 \mathrm{mg}$ daily dose of liraglutide, ${ }^{12-15}$ which reported $\mathrm{HbA}_{1 \mathrm{c}}$ falls of $1.1 \%, 1.0 \%$, $0.8 \%$ and $1.5 \%$, respectively.

A limitation of the study is the absence of data on smoking, atrial fibrillation and previous CVD in the liraglutide audit database. These limitations reflect the nature of real-world audit in that the dataset in the audit questionnaire used by participating centres was necessarily kept to a minimum to facilitate collection by busy clinicians. Another limitation is that the calculation depends upon maintenance of the observed changes in the components of the risk engine over 10 years. In addition, no modelling technique is perfect, and since the creation of the UKPDS risk engine there have been changes in diets, smoking, use of statins, use and types of antihypertensive agents, treatments for diabetes, alcohol consumption and pollution levels which might affect the validity of the tool when applied to recently collected data, and the calculations may not be generalisable to populations outside the UK. For the UK population, however, the UKPDS engine remains the best available tool to estimate the benefit likely to accrue in terms of reduced numbers of cardiovascular events and death.

We are also aware that there is a possibility of bias in that the 747 patients whose data were complete for all six items required for the UKPDS risk engine were a subset of the total of 6,959 patients. The datasets submitted by clinicians are also a subset of those patients treated by liraglutide within the UK, so we cannot exclude bias arising from factors such as less compliant patients being less likely to be included within this subset. Nevertheless, we believe this study provides a useful working basis for clinicians to discuss the magnitude of the cardiovascular risk benefit to people with diabetes treated with liraglutide in everyday practice within the UK.
Conflict of interest: $C W, S K, R H, P M, U B, J H, T H, A P, K Y A, K T$, have nothing to disclose. REJR has received speaker fees, and/or consultancy fees and/or educational sponsorships from AstraZeneca, BioQuest, GI Dynamics, Janssen and Novo Nordisk. SR is honorary secretary of ABCD. RN reports grants, personal fees and non-financial support from Lilly; grants, personal fees and nonfinancial support from Sanofi; personal fees and non-financial support from Novo Nordisk; personal fees from Jansen; personal fees and non-financial support from AstraZeneca, outside the submitted work

Funding: The ABCD Nationwide Liraglutide Audit programme was supported by a grant from Novo Nordisk. The audit was independently initiated and performed by $A B C D$, and the authors remained independent in the analysis and writing of this report.

Acknowledgement: The authors would like to thank the audit contributors (see Appendix 1 at www.bjd-abcd.com)

\section{References}

1. Marso SP, Daniels GH, Brown-Frandsen K, et al, for the LEADER Steering Committee on behalf of the LEADER Trial Investigators. N Engl J Med 2016;375:311-22. https://doi.org/10.1056/NEJMoa1603827

2. UKPDS CVD Risk Engine 2.0. https://www.dtu.ox.ac.uk/riskengine/

3. https://www.diabetologists.org.uk/GLP1_Audits/PresentationsPostersAbstractsLiraglutide.htm

4. Marso SP, Poulter NR, Nissen SE, et al. Design of the liraglutide effect and action in diabetes: evaluation of cardiovascular outcome results $\left(\right.$ LEADER $\left.{ }^{\circledR}\right)$ trial. Am Heart J 2013;166:823-30. https://doi.org/10.1016/j.ahj.2013.07.012

5. Smeeth $L$, Haines A, Ebrahim S. Numbers needed to treat derived from meta-analyses--sometimes informative, usually misleading. BMJ 1999; 318:1548-51. https://doi.org/10.1136/bmj.318.7197.1548

6. Jousilahti P, Tuomilehto J, Vartiainen E, Pekkanen J, Pushka P. Body weight, cardiovascular risk factors, and coronary mortality: 15-year follow-up of middle-aged men and women in eastern Finland. Circulation 1996;93:1372-9. https://doi.org/10.1161/01.CIR.93.7.137

7. Miller MT, Lavie CJ, White CJ. Impact of obesity on the pathogenesis and prognosis of coronary heart disease. J Cardiometab Syndr 2008;3:162-7. https://doi.org/10.1111/j.1559-4572.2008.00004.x

8. Zhao X, Huang K, Zheng M, Duan J .Effect of liraglutide on blood pressure: a meta-analysis of liraglutide randomized controlled trials. BMC Endocrine Disorders 2019;19:4. https://doi.org/10.1186/s12902-018-0332-5

9. Sun F, Wu S, Wang J, et al. Effect of glucagon-like peptide-1 receptor agonists on lipid profiles among type 2 diabetes: a systematic review and network meta-analysis. Clin Ther 2015;37:225-41.e8 https://doi.org/10.1016/j.clinthera.2014.11.008

10. Matikainen N, Söderlund S, Björnson E, et al. Liraglutide treatment improves postprandial lipid metabolism and cardiometabolic risk factors in humans with adequately controlled type 2 diabetes: a single-centre randomized controlled study. Diabetes Obes Metab 2019;21:84-94. https://doi.org/10.1111/dom.13487

11. Rondanelli M, Perna S, Astrone P, Grugnetti A, Solerte S, Guido D. Twenty-four-week effects of liraglutide on body composition, adherence to appetite, and lipid profile in overweight and obese patients with type 2 diabetes mellitus. Patient Prefer Adherence 2016;10:407-13. https://doi.org/10.2147/PPA.S97383 PMCID: PMC48180

12. Marre M, Shaw J, Brandle M, et al. Liraglutide, a once-daily human GLP-1 analogue, added to a sulphonylurea over 26 weeks produces greater improvements in glycaemic and weight control compared with adding rosiglitazone or placebo in subjects with type 2 diabetes (LEAD-1 SU). Diabet Med 2009;26:268-78. https://doi.org/10.1111/j.1464-5491. 2009.02666.x

13. Nauck M, Frid A, Hermansen K, et al. Efficacy and safety comparison of liraglutide, glimepiride, and placebo, all in combination with metformin, in type 2 diabetes: the LEAD (liraglutide effect and action in diabetes)-2 study. Diabetes Care 2009;32:84-90. https://doi.org/10.2337/dc08-1355

14. Garber A, Henry R, Ratner R, et al. Liraglutide versus glimepiride monotherapy for type 2 diabetes (LEAD-3 Mono): a randomised, 52week, phase III, double-blind, parallel-treatment trial. Lancet 2009; 373:473-81. https://doi.org/10.1016/S0140-6736(08)61246-5

15. Zinman B, Gerich J, Buse JB, et al. Efficacy and safety of the human glucagon-like peptide-1 analog liraglutide in combination with metformin and thiazolidinedione in patients with type 2 diabetes (LEAD-4 Met+TZD). Diabetes Care 2009;32:1224-30. https://doi.org/10.2337/dc08-2124 
Appendix 1. ABCD nationwide liraglutide audit contributors The following are those whom we know about

$A B C D$ nationwide liraglutide audit - initial setup, maintenance and nationwide analysis:

Ryder REJ, Walton C, Thong KY, Sen Gupta P, Cull ML, Mills AP, Crabtree T. Statistician: Blann A.
Addenbrookes Hospital: Adler A, Bejinariu E, Park A, Parker V, Sarker A, Simmons D. Altnagelvin Area Hospital: Black R N, Caskey H, Cooke B, Early R, Giff K, Hamilton L, Helmy A F, King L, Lindsay J R, McCarroll F, McDaid A-M, Mcllvor E, Moles K W, Morahan S, O'Kane M, Williams L. Antrim Area Hospital: Kennedy A. BaNES NHS Primary Care Trust: Catchpole S, Wylie S. Barnsley Hospital NHS Foundation Trust: Uchegbu E. Barnet General, London: Cohen M, Katz J, Kola B, Tanday R, Seenandan J, Steuer L. Basildon University Hospital: Mulcahy M. Bassetlaw Hospital: Kela R, Woods H. Bearwood Medical Practice: Alderman J, Bhanderi S, Matthews J, Newhouse R, Purcell J Sen Gupta P. Belfast City Hospital: Henry RW, McMullan P, Nugent A. Bensham General Hospital: Narayanan K R. Birmingham Community Healthcare NHS Trust: Bhanderi S, Cunningham B, Haughton K, Matthews J, Muralidhara K, Sen Gupta P, Shahid S, Thomas A. Bradford Royal Infirmary: González S. Brighton General Hospital: Duff B. Brighton Sussex University Hospital NHS Trust, Royal Sussex County Hospital: Burberry A. Bristol General Hospital: Croxson S. Bristol Royal Infirmary: John H, Jones L, Pople J A, Richards G. Bronglais Hospital Evans C, Jones A M, Kotonya C, Phillips L, Powell P, Saunders H. Calderdale Royal Hospital: Mon Zin Tun E. Cape Hill Medical Centre: Bhanderi S, Child D, Chitnis J, Gardner G, Maan P, Matthews J, Merali A, Sen Gupta P. Causeway Hospital, Coleraine: Davidson E, Diong K L, Glass M, Hutchinson K, Kassim S B, McKee M, Ryan M F, Spiers K, Woodend J. Chase Farm Hospital: Baynes, C, Lomas J, Russell S. Cheltenham General Hospital: Evans A, Gray H, Lock-Pullan P, Phillips S. City Hospital Birmingham (SWBH): Basu A, Bedi T, Bhanderi S, Blann A, Burbridge W, Cull M L, Cutler J, De P, Guthrie S, Irwin S, Lee B, Lloyd F, Matthews J, Mehrali T, Mills A P, Ryder R E J, Sen Gupta P, Stevenson-Mort J, Thong K, Zzizinger A. City Hospitals, Sunderland: Carey P, Coates J A, Lee A, Nayar R, Ogilvie P, Purvis A, Todd J, Walton K. Conquest Hospital: Batson D, Castro E, Combes A, Dashora E, Edwards V, Govindan R, Kumar S, Morris R. Cumberland Infirmary Centre: Graham S, Higgins N, Mason J, Redgate J, Routledge A, Simpson E, Vithian K. Darlington Memorial Hospital: Bishop D. Derriford Hospital: English P, Fox T, Tambal A, Wotton F. Dewsbury District Hospital: Bissell J. Downe Hospital Northern Ireland: Whitehead H. East Lancs Hospitals NHS Trust: Ali A, Demssie Y, Glew M, Jones G, Jostel A, Littley M, Mishra M, Ramtoola S, Wilkinson R. East Surrey Hospital: Chinnasamy E, Prajapati C, Sennik D. Eastbourne District General: O'Donnell H. ELPCT: McKane C, Procter W, Sarsfield J, Wilkinson R. Forth Valley Royal Hospital: Barwell N, Bramley A, Buchanan L, Currie J, Davidson E, Devlin K, Doig J, Kelly C, MacDonald P, Mackenzie A, Mackintosh L, Peden N, Ryan L, Simpson C, Whitty H. Friarage Hospital: Kamaruddin M S, Leek C, Owen K. Frimley Park Hospital: Beebeejaun M, Tringham J. Furness General Hospital: Banerjee M, Obale B, Pearce D, Tong M. George Eliot Hospital: Patel V. Gloucestershire Royal Hospital: Gan K S, Mahajan T, Saunders S, Ulahannan T. Guy's and St Thomas' Hospital London (Guy's \& St. Thomas' NHS Trust): McGowan B, Abbas N, Sen Gupta P, Da Costa R, Georgieva E. Harrogate Hospital: Brown D, El-Laboudi A, Hammond P. Hinchingbrooke Health Care NHS Trust: Bejinariu E, Krishnan S, Mathews A, Walland K. Huddersfield Royal Infirmary: Moisey R. Hull Royal Infirmary: Marinceu D, Sathyapalan T, Sugunendran S, Walton C, Waqas. Hunslet Health Centre: Muneer K. King's College Hospital: Amiel, SA, Hunt K F, Lee M, Nathan Y, Pernet A, Raeburn J, Sen Gupta P, Stothard B, Vitello S. Lagan Valley Hospital: Au S, Brennan U, Carr S, Harding J, Harper R, MacDonald P, McLaughlin D, Moore L, Mulligan C, Whitehead H. Lancashire Teaching Hospital, Chorley Hospital: Rajbhandari S M, Whittaker J. Lancashire Teaching Hospital, Royal Preston Hospital: Rajbhandari S M, Whittaker J. Leicester General Hospital: Gregory R, Jackson S, Kong M-F, Tarigopula G. Leicester Royal Infirmary: Htike ZZ. Leigh Infirmary: Fatima J, Pearce S. Lister Hospital: Barker L, O' Donnell L. Llandridod Wells: Powell P. London Medical (Private Medical Centre): Abraham C, Abraham R, Bowden J, Genovezos S, King L, Spahiu E, Thomas S. Mid Yorkshire Hospitals NHS Trust (Pinderfield Hospital, Wakefield, West Yorkshire): D'Costa R, Kadis T, Maycock J, Nagi D, Seddon L. Minerva Centre: Caunce K. Monklands Hospital: Sandeep T C, White A. Musgrove Park Hospital (Taunton \& Somerset NHS Foundation Trust): Adams S, Andrews R, Close C, Douek I, Dunlop A, Lambert P, Thomas J, Watson J. New Cross Hospital Wolverhampton: Katreddy V, Khalid Y, Krishnasamy S, Nayak A U, Singh B
M. Newham University Hospital: Balakumar Y, Gelding S, Menon R, Rayanagoudar G. NHS Tayside (Ninewells Hospital/Perth Royal Infirmary): George P, Leese G. Northumbria Diabetes Service: Strey C. Orpington Hospital: Casiglia D. Pendyffryn Medical Group: Morrison C L. Pennine Acute Hospitals Trust: Adams L, Aherne D, Ahmad M, Allen G, Anderson K, Asam M, Atherton L, Balmuri M, Benton M, Berry M J, Bhatnagar D, Bood A, Broude H, Byrom J, Cheer K, Dang C, Emsley C, Farook S, Fletcher M, Flight W, Garg R, Hafeez K, Hall D, Higham C, Holland K, Hunsdale D, Jagadhish, Jani M, Jennings R, Jostel A, Joyce P, Kalavalapalli S, Khan S, Khurana R, Kouta S, Kumar S, Lea S, Lewthwaite P, MacDonald L, Malik I, Mawdsley J, McAllister G, Meredith K, Meth-Cohn D, Mishra B, Moore J, Mustafa A, Narasimhan S, Naray S T K, Nazir K, Norris A, Nune A, Picton M, Prakash P K, Prouten J, Rathur H, Roberts K, Rothwell N, Rowles S, S Rashid S, Savage M, Shah S, Shingler W, Smith G, Smith K V, Smithurst H, S-Samavi M, Stott R, Sudagani J, Suliman M, Tarpey S, Taylor A, Taylor E, Weaver A, West A, Wild J, Wiles P. Pilgrim Hospital: Htwe N, Jacob K. Pontefract General Infirmary: Bissell J. QE 2 Hospital, Welwyn Garden City: Ali S, Chirayath H, Darzy K, Ford M, George S, Kaplan F, Lecamwasam V, Perera S, Qureshi S A, Scott R, Thay T, Winocour P, Wyman D, Zalin B. Queens Romford: Khan K, Nkonge F. Roebuck House (Surgery 1): Dicker C, Rowan J, White T. Rotherham General Hospital: Franke B, Muzulu S, Salam S. Royal Blackburn Hospital: Demssie Y, Glew M, Jones G, Jostel, A, Littley M, Mishra M, Prouten J, Ramtoola S, Wilkinson R. Royal Devon and Exeter Hospital: Aziz A, Babiker T, Brooks A, Lockett H. Royal Gwent Hospital: DaCruz T, Kamath C, Obuobie K. Royal Infirmary of Edinburgh: Inkster B, McLaren J, Zammitt N. Royal United Hospital Bath: Allen K, Higgs E, Naik S, Robinson A, Ward A. Royal Victoria Hospital Belfast: Cooke B, Hunter S, McErlean U. Sandwell General Hospital (SWBH): Bhanderi S, Davies P, Matthews J, Rock K, Sen Gupta P, Thong K Y. Sedlescombe House Surgery St. Leonards-on-Sea: Cooper S, Joyce L, Kaliniecki J. Singleton Hospital, Swansea: Udiawar M. Smethwick Medical Centre (GP) (SWBH): Bhanderi S, Harrington J, Matthews J, Sen Gupta P. Southern General Hospital: Gallagher S, Hutchieson A, Kennon B, Kernohan A, Semple C, Struthers S. Southmead Hospital: Gaffar I. St Bartholomew's and The London NHS Trust: Coppack S, Gouveia C, Khan R, Waugh J. St George's Hospital NHS Trust: Ahmed F W, Bano G, Firth P, Flanagan A, O'Brien J, Patel N, Wilson Z. St John's Hospital Livingston: Adamson K, Teoh W L. St Mary's Hospital, IOW: Al-Mrayat M, Verlekar P. St Mary's Hospital, London: Qureshi S A. St Stephen's Gate Medical Practice (Norfolk PCT) (SSGMP): Haylock C. Stepping Hill Hospital: Kong N, Mumby C. Stirling Community Hospital (Stirling Royal Infirmary): Barwell N, Bramley A, Buchanan L, Currie J, Davidson E, Devlin K, Dewar L, Doig J, Kelly C, MacDonald P, Mackenzie A, Mackintosh L, Peden N, Ryan L, Simpson C, Whitty H. Stobhill Hospital, Glasgow: Acquah R, Drummond R, Gordon D, Leggett G, MacEwen A, McKenzie J, McLaren J, Smith C. Stoke Mandeville: Stokes V. The Ipswich Hospital: Astle J, Fowler D, Morris D, Parkinson C, Rayman G, Thomas M. Torbay Hospital: Dimitropoulos I, Dyer R, Lissett K, Paisey R, Smith J, Weekes C. Trafford General Hospital: George A, Hopewell L, Snell A, Stephens W P. Tyrone County Hospital: Bradley P, Evans H, Hameed A, Helmy A, McGirr B, Monaghan S, Patterson H. Ulster Hospital: Au S, Brennan U, Carr S, Donnelly R, Harding J, Harper R, MacDonald P, Mcllwaine W, McLaughlin D, Moore L, Mulligan C, Trinick T, Whitehead H. University College Hospital, London: Lunken C, Patel D. University Hospital of Durham: Kashif M. University Hospital of Hartlepool: Anthony S, ljaz S, Jones S, Sinclair J, Worrall E. University Hospital of North Tees: Dobson M, MacLeod J, Manohar S P, Mehaffy J, Presgrave M, Pye S, Robinson M, Roper N, Worrall E. Victoria Hospital Kirkcaldy (Kirkcaldy Acute Hospitals NHS Trust): Burns D, Chalmers J, Duncan C. Warrior Square Surgery: Adams S, Dunlop A, Ottaway L. West Suffolk Hospital: Clarke J, Moss A. Western General Hospital: Inkster B, Kochhar R S, Mathur S, Mclaren, Zammitt N. Western Isles Hospital: Achar K N. Westmoreland General Hospital: Banerjee M, Obale B, Pearce D, Tong M. Wharfedale Hospital: Amery C. Wiltshire NHS Primary Care Trust: Hall B, Hillier N. Wrexham Maelor: Dixon A. Wythenshawe Hospital (UHSM) Younis N. Yeovil District Hospital NHS Foundation Trust: Bickerton A, Crocker M, Pramodh S. Ysbyty Ystrad Mynach: Premawardhana L D. 